\title{
DA RELIGIÃO DO JURAMENTO AO JURAMENTO SECULARIZADO: CONCLUSÕES DE UM ESTUDO SOBRE A EVOLUÇÃO DO JURAMENTO PROCESSUAL NA COLÔMBIA DURANTE O SÉCULO XIX ${ }^{*}$
}

\author{
FROM THE RELIGION OF OATH TO THE SECULAR OATH: CONCLUSIONS OF \\ A STUDY ABOUT THE EVOLUTION OF PROCESSUAL OATH IN COLOMBIA \\ THROUGH THE NINETEENTH CENTURY
}

Andrés Botero-Bernal ${ }^{* *}$

\begin{abstract}
RESUMO: este artigo apresenta a conclusão de um trabalho maior que traz novas luzes sobre o processo de laicização do juramento processual ao longo do século XIX colombiano. Baseado em fontes primárias (processos judiciais, normativas e causas célebres) e secundárias, analisa-se o valor do juramento como garantia de verdade no marco da finalidade cultural do processo judicial, a evolução do juramento (política e processualmente) na modernidade e a passagem paulatina do juramento religioso ao secularizado no processo judicial colombiano. Discute-se, ainda, a forte relação entre religião (tanto a culta como a popular) e o juramento processual, o que contribui para a identificação das características mais importantes da cultura jurídica do século XIX.
\end{abstract}

PALAVRAS-CHAVE: Juramento judicial. Laicização. Processo judicial. Religião. Verdade.

ABSTRACT: This paper presents the conclusions of a large research that brings new lights into the process of laicization of the judicial oath through the nineteenth century in Colombia. Based on primary (trials, rules and literature - causas célebres) and secondary sources, it's

\footnotetext{
* Este artigo é fruto do projeto de pesquisa A cultura jurídica na Antioquia do século XIX, financiado pela Universidad de Medellín, e executado dentro do Grupo de Pesquisas Jurídicas registrado no COLCIENCIAS na categoria A1. Este texto foi também apresentado no III Encontro do Instituto Latino-Americano de História do Direito, em Morélia-Michoacan (México), em 06 de outubro de 2011. Quero agradecer ao historiador Yoer Castaño, que me ajudou a transcrever vários processos judiciais, e a resolver muitas questões paleontológicas e diplomáticas sobre os registros, à professora Andrea Macia (Universidad Autónoma de Madrid) - que corrigiu o primeiro esboço e fez sugestões importantes - e aos estudantes de direito e assistentes de pesquisa Estefanía Acosta, Juliana Osorio y Juan Camilo Martínez - que colaboraram na elaboração do texto final. Expresso também meu agradecimento aos funcionários do Archivo Histórico Judicial de Medellín (AHJM), que me permitiram tirar o máximo proveito dos inigualáveis fundos arquivísticos que preservam, bem como aos pesquisadores, estudantes e funcionários do Max Planck Institut für Europäische Rechtsgeschichte (Frankfurt am Main), pelo espaço e pelo tempo vitais, os quais facilitaram meus estágios de pesquisa naquele local, e sem os quais não se poderia chegar a uma conclusão bem sucedida desse trabalho. Obrigado a todos.

** Bacharel em Direito pela Universidad Pontificia Bolivariana; licenciado em Filosofia e Letras pela Universidad Pontificia Bolivariana; especialista em docência universitária pela Universidad Santo Tomás; especialista em contextualização psicossocial do crime pela Universidad San Buenaventura; diplomado em Estudos Avançados pela Universidad de Huelva; mestre em storia e comparazione delle istituzioni politiche e giuridiche dei Paesi dell'Europa Mediterranea pelas Universidades de Messina, Milão, Autónoma de Madrid y Córdoba; doutor em Direito pela Universidad de Buenos Aires. Professor-pesquisador da Universidad Industrial de Santander (Colômbia).E-mail: botero39@gmail.com
}

Tradução do artigo: Danielle Regina Wobeto de Araujo, mestre e doutoranda em História do Direito pelo Programa de Pós-graduação em Direito da Universidade Federal do Paraná. E-mail: daniius76@hotmail.com 
analyzed the value of the oath as a guarantor of truth within the framework of the cultural purpose of the judicial procedure, the evolution of the oath (politically and judicially) in the modernity and the gradual passage of the religious oath to one of legal form into the Colombian judicial process. It also discusses the strong relationship between religion (both, educated and popular) and the procedural oath, all with the goal to contribute to the identification of the most important characteristics of the nineteenth-century legal culture.

KEYWORDS: Judicial oath. Judicial process. Laicization. Religion. Truth.

\title{
INTRODUÇÃO
}

\begin{abstract}
Virá um tempo em que o juramento será supérfluo; mas, por ora, é indispensável, pelo que pode e deve ser prestado também pelos espíritos mais iluminados. ${ }^{1}$
\end{abstract}

Karl Gottlob Anton

\section{SOBRE O PLANO DE ESCRITA DO ARTIGO}

O presente trabalho apresenta as conclusões de um estudo maior sobre a evolução do juramento judicial na Colômbia do século XIX. O texto original, ainda inédito, abrange vasta jurisprudência, tomada de uma mostra representativa dos registros judiciais do século XIX, e paralelamente traz um marco histórico, normativo e conceitual, que permite ao leitor, nem sempre familiarizado com a história colombiana, compreender os casos processuais apresentados. Traz, ainda, uma lista do juramento que prestavam as partes, as testemunhas, os peritos, os devedores e, em alguns casos, os acusados (estes últimos em processos criminais, especialmente ante juízes leigos). Na sequência apresentam-se, de forma sucinta, as principais obras acadêmicas que aportam elementos para a compreensão da própria instituição do juramento. Por último, de forma a concluir o trabalho (justamente a parte que agora se apresenta), elabora-se um marco de compreensão mais completo do transcorrer do juramento processual, nosso objeto de estudo - sem ânimo de criar uma categoria estática - dentro de várias tensões que apresentaremos na sequência.

Por fim, a forma pela qual optei por escrever o texto corresponde, em certa medida a uma tentativa de brincar com o modo indutivo, muito próprio na colocação em cena de certos textos etnográficos. Vale dizer, terminei por apresentar, no mencionado trabalho maior, primeiro os materiais, que vão projetando certas elaborações teóricas parciais, para logo apresentar um corpus teórico trazido por aqueles que nos precederam - e com muito melhor tino, nos estudos sobre o juramento - para finalizar com meu marco de compreensão do

\footnotetext{
${ }^{1}$ Tradução do autor a partir do alemão. No alemão da época: "Es kann also wohl eine Zeit kommen, wo er überflussig seyn wird; ietzt aber ist er unentbehrlich, und kann und muss auch von den Aufgeklärtesten geleistet werden".
} 
fenômeno, que incluiu tanto as fontes primárias como as secundárias, conjunto que corresponde a um axioma científico que não se pode passar por alto: apresentar e estudar (o caso) antes de julgar(á-lo) em um sentido acadêmico, mas não moral.

Agora, por limites de espaço, tomei as conclusões do aludido trabalho, ou seja, aquela parte em que apresento meu marco de compreensão do juramento processual do século XIX, que foi escrita de maneira que possa ter algum sentido próprio sem passar pelo resto do trabalho. Com base nas ditas conclusões, elaborei o presente artigo; não será possível, no momento, utilizar todo o material recolhido e explorado no texto maior. Esperamos, em um futuro próximo, apresentar ao público o texto completo.

\section{FONTES}

Passando pelas fontes primárias, ponto indispensável em toda pesquisa da história do direito, consultamos fundamentalmente os registros judiciais do Arquivo Histórico Judicial da Cidade de Medellín. Nesse Arquivo havia, no final de 2003, 6663 registros judiciais; em sua grande maioria, do século XIX. Assim, contando com uma margem de erro de 3\%, e um nível de precisão de $80 \%$, fazia-se necessária a consulta e leitura de 427 processos judiciais do século XIX, com base nos quais se fez a leitura e registro para uma aproximação qualitativa das fontes.

Fica claro que com o universo de consulta mais restringido (uma vez que abrange processos de outros séculos) a mostra escolhida implica um nível de precisão ainda mais alto, na medida em que somente se consultaram processos judiciais do século XIX. Como já foi dito, cada um desses registros estudados foi devidamente anotado, para logo serem transcritos em várias seções de aproximadamente 190 registros, com o objetivo de permitir sua consulta imediata fora do Arquivo. O trabalho completo de registro e transcrição dos processos judiciais durou pouco mais de quatro anos, em três turnos. O primeiro deles entre 2003 e o começo de 2004, o segundo de 2005 a 2006 e, por fim, uma última parte de 2008 a 2009. Aqui vale a pena enfatizar que não nos limitamos a analisar as sentenças (vistos), mas os registros completos, pois de tal maneira poderíamos rastrear a linguagem que permeia o processo.

Obviamente, esse artigo, por problemas de espaço, não poderá dar conta de todos os processos fichados, nem sequer de todos aqueles transcritos, razão pela qual só mencionarei alguns - aqueles que considerei representativos do estilo próprio do período de que se fala. 


\section{INTENÇÃO INVESTIGATIVA}

Outro aspecto relevante a se mencionar nesta introdução relaciona-se com uma intenção que atravessa não apenas o processo investigativo, mas também este texto. Esta pesquisa não é uma pesquisa normativa do instituto processual do juramento, ainda que não possamos nos desvincular totalmente da norma para entender o marco do qual se fala. Também não é essa uma pesquisa histórico-institucional em sentido estrito, pois não divagaremos tanto sobre o dito pelos autores clássicos acerca do tema, nem sobre a forma como se concebia o juramento como liturgia do poder no Ocidente - aspecto que Prodi $(1992)^{2}$ já explorou magistralmente -, mas meditarei a propósito de um tipo especial de juramento (aquele feito dentro de um registro para garantir a verdade de certa prova), dentro dos processos judiciais abrigados pelo poder civil (ou seja, descartados os processos canônicos), em um marco temporal mais limitado (o século XIX, ao qual aludiremos também como século liberal) e em um espaço mais reduzido (Colômbia ${ }^{3}$; não obstante, temos que dizer que os casos apresentados correspondem à região da Antióquia, mas que, mutatis mutandi, podem corresponder a outras regiões do País). Deixamos claro que, sem o respaldo da história institucional, seria impossível compreender o transcorrer do juramento dentro do processo, pelo que se dará conta do marco conceitual reiteradamente ao longo deste artigo.

Então, o que se busca com este trabalho investigativo? Dar um passo a mais para poder "identificar, a partir dos textos jurídicos, as características essenciais da sociedade que lhes deu origem" (LORENTE, 2007, p. 76); isto é: um trabalho de culturas jurídicas (ou, caso se prefira, de law in action ${ }^{4}$ ), que permite, muito melhor que a história normativa e institucional, dar conta da complexidade nos cruzamentos entre direito e cultura. Tal como disse Petit (2005, p. 251-2):

En este sentido, no sería el Derecho - presente o pasado - el principal objeto de observación, sino todo aquello que, a propósito del Derecho, han podido decir y escribir personas insertas en ciertas instituciones (tribunales, universidades, parlamentos) encargadas de la producción de textos reputados jurídicos.

\footnotetext{
${ }^{2}$ A metáfora do juramento como liturgia do poder se encontra no decorrer de toda a obra; por exemplo, à página 18 .

${ }^{3} \mathrm{O}$ leitor não familiarizado com a história da Colômbia deve ter presente que, ao longo do século XIX, o País teve vários nomes: Virreinato de la Nueva Granada; Provincias Unidas de la Nueva Granada; La Gran Colombia; La República de la Nueva Granada; La Confederación Granadina; Los Estados Unidos de Colombia e, finalmente, República de Colombia. Aqui se decidiu por um tema de economia estilística - referir-nos-emos a Colômbia, sem mais.

${ }^{4}$ Com um uso bem interessante, a partir do início do século XX: por parte da jurisprudência sociológica, cf. POUND (1910, p. 12-36). E, da sociologia do direito, cf. EHRLICH (1922, p. 130-45). Não obstante, não se podem equiparar em tudo os estudos de cultura jurídica com os de Law in Action; porém, no que nos cabe, bem se poderia considerar que o que aqui se pretende encaixa em ambos os conceitos.

Revista da Faculdade de Direito - UFPR, Curitiba, vol. 60, n. 1, jan./abr. 2015, p. 215-246.
} 
E não poderia ser de maneira diferente, visto que se estuda justamente uma instituição que vincula não somente a religião (tanto em sua faceta universal - teologia como na faceta que se vive cotidianamente pelos povos neogranadinos - religião popular) com o processo judicial (que ocupa um lugar privilegiado no que se entende por Direito na cultura, pois comunica a vida com a norma em seu sentido mais amplo), mas também que ali se joga a relação íntima do indivíduo com os poderes institucionalizados, como são o Estado e a Igreja. Estes aspectos, por assim dizer, não teriam sido levados em conta se não nos debruçássemos sobre o essencial da cultura jurídica que serve de marco ao juramento processual.

\section{FORMA}

No que concerne aos aspectos mais formais, ainda que, não por isso, menos importantes, devemos destacar que os textos dos processos judiciais, adiante citados, foram atualizados, em sua ortografia e abreviações, para o espanhol contemporâneo, para permitir o seu melhor entendimento. Não obstante, a estrutura narrativa e a forma de redação se mantiveram iguais aos textos originais. Além disso, continuamente se aludirá ao Arquivo Histórico Judicial de Medellín, localizado nas instalações da Universidade Nacional, sede Medellín.

O texto foi escrito principalmente na primeira pessoa do plural, especificamente por duas razões. A primeira é porque o trabalho foi fruto do meu ensino, em diálogo com os colegas e com a ajuda constante de vários assistentes de pesquisa. Não há, portanto, razão para se acreditar em um solipsismo acadêmico; pelo menos, não neste trabalho. A segunda, porque cria um efeito interessante do envolvimento do leitor com o autor, uma certa cumplicidade necessária no prazer da leitura e aprendizagem crítica, que, acredito, é alcançado mais facilmente quando se fala de "nós" em vez de "eu".

\section{CARACTERÍSTICAS E DEFINIÇÃO DO JURAMENTO PROCESSUAL}

Agora, recapitulando aquele trabalho maior do qual se falou na introdução, já podemos apresentar nossas conclusões sobre o juramento processual, que sempre serão parciais, por motivos que trataremos mais à frente. Porém, antes de qualquer coisa, a partir do caminho que percorremos até o momento podemos começar a anotar as características da instituição objeto de estudo, no período do qual nos ocupamos. Em primeiro lugar, há que se 
atender à denominação: juramento assertivo, afirmativo, processual, judicial, testemunhal? Como determiná-lo? $\mathrm{Na}$ época se denominava simplesmente juramento assertivo ou afirmativo, mas Prodi (1992, p. 15-6) mostrou que a divisão tradicional do juramento entre assertivo (ou afirmativo) e promissório (sendo o primeiro o que sustenta uma afirmação sobre a veracidade ou a verdade de um testemunho ou de um fato - cuja sede natural é o processo judicial - e o segundo o que sustenta uma promessa de fidelidade e lealdade a um poder, ou de pertencimento a um corpo político - cuja sede natural é a política) é tão tênue que não se poderia seguir em um estudo analítico. Sua crítica centra-se no que não se pode diferenciar claramente - se uma afirmação que se sustenta com um juramento é um testemunho ou uma promessa (nesse caso, de dizer a verdade), e dita classificação pode perder o lado político que há tido a evolução do juramento em sede processual. Assim, Prodi deixa claro que o juramento assertivo tem tanto de testemunho como de promessa, pelo que ao estudo do juramento político, como ele prefere chamá-lo, faz-se necessário analisar, de alguma maneira, o desenvolvimento do juramento em sede processual ${ }^{5}$. Portanto, Prodi (1992) prefere, simplesmente, o uso do termo "juramento político"6 para designar o juramento de fidelidade e de lealdade ao poder, e usa em sua obra o termo "juramento em sede judicial ou processual" para referir-se ao juramento de dizer a verdade ou que o que se disse foi verdade, com sede em um processo judicial.

Isto nos leva a outra pergunta sobre a denominação. Chamá-lo juramento testemunhal atendendo ao fato que é feito pelas testemunhas seria chamar a instituição por uma de suas espécies, visto que nem todo juramento, no sentido e no período que nos interessa, é feito pelas testemunhas: os peritos juram ter dito a verdade, segundo sua ciência, e os demandantes juram ter dito a verdade em suas petições.

Agora, chamá-lo de judicial significaria que este juramento é próprio dos juízes, o que não é certo: primeiro porque é o juiz que recebe o juramento - ainda que emita um

\footnotetext{
${ }^{5}$ Inclusive, se nos ativéssemos aos catecismos analisados, haveria três tipos de juramento: o afirmatório (quando juramos uma afirmação de algo que ocorreu ou ocorre), o promissório (quando se promete algo com juramento) e o executório (quando se lançam pragas caso não seja verdade o que se disse). Cf. transcrição do catecismo granadino de Sacromonte em RESINES (2002, p. 271, capítulo 33). Igualmente, o Catecismo do Santo Concílio de Trento, seguindo esta tradição, alude a dois tipos de juramento, o assertivo e o compromissório (IGLÉSIA CATÓLICA, 1803, p. 350-1). Porém, seguindo Prodi (1992) e a partir de parâmetros analíticos, esta classificação não seria a mais apropriada. Onde encaixar o testemunho jurado? Resulta que é um juramento sobre a verdade no que souber a testemunha, pelo que poderia ser afirmatório; porém, geralmente se faz no início da declaração, com o qual é uma promessa de dizer a verdade, pelo que seria, pois, promissório; e, finalmente, a testemunha, em sua qualidade de cristão, sabe da ameaça que lhe recai na hipótese de mentir, pelo que facilmente é executório.

${ }^{6}$ Lorente (2007), por seu objeto de pesquisa mais específico, refere-se a "juramento constitucional", pois, em última análise, os juramentos foram feitos sob a Constituição gaditana, mas continuam sendo exemplos de juramento político.
} 
juramento político de lealdade ao Estado e à Constituição no momento de sua investidura no cargo -, e ainda porque o juramento nem sempre se dá perante instâncias judiciais em sentido estrito, podendo dar-se perante o escrivão, inspetor ou fiscal, entre várias outras opções possíveis. Inclusive, ao longo do século XIX, o juramento se tornou cada vez mais um assunto secretarial, como veremos na sequência.

Por esta razão que, sem querer criar uma categoria ontológica - visto que, se em algo estamos de acordo com Prodi (1992, p. 13, 20), é que se trata de uma instituição dinâmica e complexa ${ }^{7}$, o chamaremos, sem mais, juramento processual, para indicar que se faz dentro de um processo judicial, em seu sentido amplo (incluindo, até mesmo, cenários processuais sem intervenção do juiz).

Em segundo lugar, o juramento processual, como se convencionou chamar ao feito dentro do processo com ânimo de se obter a verdade sobre a qual deve haver um pronunciamento judicial (entendendo o termo juiz em um sentido amplo) não pode ser confundido com o juramento político, tampouco dele separar-se (ou de sua derivação constitucional), distinção que explica, por exemplo, as diferenças que em um e outro se fazem sobre quem jura. No juramento político, jura quem é considerado pessoa idônea no mundo político liberal para comprometer suas vidas, suas fortunas (destino) e bens a uma causa maior, e por isso recebe a consideração de cidadão; enquanto que, no juramento processual, jura quem tem algo a contribuir para a construção da verdade dos fatos e alguma consciência do que está em jogo com seu juramento: sua alma. Assim, enquanto as mulheres e os escravos possuíam, politicamente, restrições para jurar por não serem cidadãos - embora Lorente (2007, p. 91, 101) nos dê exemplos de juramentos de mulheres e escravos em cerimônias coletivas no constitucionalismo gaditano, mas que o faziam justamente por não serem cerimônias individuais -, no juramento processual o limite era a consciência do ato, se bem que isso não obstava que um maior de 14 anos jurasse em um processo; porém, neste caso, haveria que se nomear para ele um curador que o "acompanhasse" (aconselhamento e representação) durante seu testemunho ${ }^{8}$. Não obstante, como já se disse, um e outro compartilham de uma mesma essência religiosa e um mesmo processo de secularização do qual trataremos mais adiante.

\footnotetext{
${ }^{7}$ O juramento como instituição dinâmica é uma ideia que se repete ao longo do texto.

${ }^{8}$ Por exemplo, cf. ARCHIVO HISTÓRICO JUDICIAL DE MEDELLÍN. Folio 2r, Documento 2839, 1845: "En el mismo día hizo el señor Juez comparecer al señor Alejandro Zea a quien por ser menor de edad se le nombró de curador al señor José María Upegui y a su presencia se le recibió juramento que hizo conforme a derecho por Dios y su santa cruz y siéndolo con arreglo a los autos antecedentes dijo..." 
Em terceiro lugar, deve-se considerar que, pelo menos à época com que nos ocupamos, o juramento tem um claro sentido de aportar a verdade ao processo, do que está ciente diretamente aquele que jura ${ }^{9}$. E ocorre que o juiz, nestes momentos (algo que se perderá nos movimentos de longa duração ${ }^{10}$ dentro de uma complexa confluência de diferentes processos históricos), é antes de tudo uma figura de balanço/equilíbrio social que, aplicando a justiça aos casos concretos (uma rude equidade), consegue desfazer os erros e tapar os buracos dos conflitos que põem em risco a coesão social (ainda estamos distantes, especialmente na primeira metade do século XIX, do juiz que considera que sua função é a mera aplicação das normas estatais), mas para isso, para o cumprimento de uma função que, ideologicamente, vai além das fronteiras da norma jurídica, requer-se saber o que aconteceu, a verdade dos fatos, com o que se acode ao principal sistema de administração de verdade de sua época, que é o caso da religião. Desta forma, reflete-se no processo judicial o espírito cristão no qual "o questionamento pela Verdade é, ao mesmo tempo, um questionamento pela Justiça”. (MARTÍNEZ, 2012, p. 220)

Tal afirmação se torna ainda mais clara com os ensinamentos de Martínez (2012, p. 221-2), quando analisa o processo canônico no Antigo Regime:

¿Qué se busca con el proceso? Ya no se trata de reparar la paz social o, mejor dicho,
no se trata solamente de reparar la paz social conculcada; la misión del proceso es
hallar la verdad de los hechos, tal y como realmente sucedieron, tal y como se
desarrollaron en el pasado, para provocar el convencimiento del juez y, en
consecuencia, para que sobre tales hechos caiga el peso de la norma, se examinen
con arreglo a ésta, y se tome una decisión capital, sin perjuicio del legítimo juego de
la equidad.

A religião, verdade por si mesma nesta sociedade, dá aval às afirmações de uma pessoa, amedrontando sua consciência com todo tipo de males terrenos e do além, pelo que o juiz pode dar credibilidade ao testemunho. Isso supõe, pois, que a perda do valor simbólico do juramento caminha ao lado, ainda que em ritmo diferente, da perda de confiança do juiz na capacidade de ameaça da "religião do juramento" (fruto de uma laicização) e, por fim, também perderá a confiança de que a ameaça estatal evite a mentira (passando o juramento ao

\footnotetext{
${ }^{9}$ Recordemos um caso já visto: "En la villa de Marinilla a trece de octubre de mil ochocientos cuarenta y cinco la parte presentó por testigo al señor José López, vecino en esta villa, a quien el señor Juez previa la lectura del artículo que refiere el cuatrocientos treinta y tres de la ley $1^{\mathrm{a}}$, P. $4^{\mathrm{a}}$, T. $2^{\mathrm{o}}, \mathrm{R}$. G. le recibió juramento el que hizo por Dios Nuestro Señor y su santa cruz; bajo de cuyo cargo y gravedad prometió decir verdad en lo que supiere y le fuere preguntado y siéndolo en virtud del anterior interrogatorio responde...". (ARCHIVO HISTÓRICO JUDICIAL DE MEDELLÍN. Folio $1 v$ y $2 r$, Documento 1419, 1833)

${ }^{10}$ Aqui usamos o conceito de Braudel (1980, p. 60-106), no sentido de que na realidade confluem processos de longa, média e curta duração.
} 
mundo do supérfluo ${ }^{11}$ ); assim, há uma reconfiguração do valor simbólico dos diferentes meios de prova de que dispõe o juiz. Então, o juramento foi, antes de tudo, uma garantia da verdade do informado, um reforço que permitiu dar confiabilidade ao testemunho de uma testemunha, um perito, um sujeito processual qualquer, gerando uma crença segura no juiz de que estava no caminho certo para chegar aos fatos, tal como se sucederam, para daí proceder à sua valoração, reconstruindo o equilíbrio social.

Em quarto lugar, o juiz e seu escrivão - mais tarde, seu secretário - são os que fazem prestar o juramento e aqueles que recebem as informações da testemunha, do perito ou da parte processual, atuando em uma dupla direção: são testemunhas do juramento e deverão reconfigurar as múltiplas verdades ditas dentro do processo em uma só (e suposta) verdaderealidade para observar onde se produziu aquilo que deve ser reequilibrado. Isso explica, ademais, que, à medida que o juramento perde seu valor simbólico, o juiz vai deixando esta formalidade - cada vez mais vazia - à competência do secretário, ora porque o juiz já não acredita mais no juramento como garantia de verdade, ora porque o juiz conta com outros sistemas de administração da verdade, que são mais confiáveis e sem que haja entre eles a mediação de um juramento.

Em quinto lugar, o juramento, no século liberal, ainda que perca muito de sua força inicial se comparado ao dos séculos anteriores, não deixa de cumprir as características básicas anotadas por Lévy-Bruhl (1959, p. 385-96) e desenvolvidas por Prodi (1992, p. 22-3); a saber: i) é fundamentalmente oral e ligado à sacralidade da palavra e a fórmulas rigidamente prefixadas (isso se torna claro quando o papel dos registros só dá conta da formalidade efetuada na frente do juiz, de maneira oral); ii) supõe-se a presença daquele que jura e da comunidade que se predispõe a participar do rito (nesse caso, do escrivão-secretário e do juiz, e, em alguns casos, ante as testemunhas designadas para este fim); iii) comporta, implícita ou explicitamente, a maldição para quem jure em falso ou não comporte-se como o prometido (que pode ser, como já vimos, produto de forças metafísicas ou do Estado mesmo); iv) vem acompanhado de gestos e rituais visíveis (como cruzar os dedos, persignando-se, etc.); v) está conectado com um sacrifício, com um lugar ou objeto sagrado (a Bíblia e o crucifixo são os mais comuns que encontramos nos processos judiciais de princípios do XIX); e vi) é uma espécie de ordália, pois se deixa, em muitas oportunidades, o castigo nas mãos de Deus (especialmente quando o juiz não tem maneira de coagir devidamente o perjúrio com sanções estatais, ainda que esta ameaça bem poderia entrar na terceira característica).

\footnotetext{
${ }^{11}$ Para Lévy-Bruhl (1959, p. 394), o passo do juramento ao supérfluo se deve à perda do mistério que o envolvia; isto é, por seu desencantamento fruto da marcada laicização. 
Assim, podemos começar a construir uma definição para os elementos já vistos no período de recorte. O juramento processual, então, é uma instituição que assegura o acesso à verdade em um processo judicial, fornecendo confiabilidade ao que foi dito por uma das partes no processo, uma testemunha ou um perito, por meio de uma ameaça religiosa (seja da religião popular, seja da doutrina universal da Igreja) e/ou uma ameaça estatal, principalmente penal, mediante uma forma religiosa e/ou legal, quer no início do testemunho (estabelecido como uma promessa de dizer a verdade) quer no final (estabelecido como uma afirmação de que o que foi dito é verdade), e é essencialmente oral (embora haja o registro de sua realização), feito com fórmulas pré-definidas, repetido na presença de quem jura e recebido pelo escrivão, secretário ou juiz.

\section{MOMENTOS DAS FONTES JUDICIAIS: JURAMENTO RELIGIOSO, TRANSIÇÃO E JURAMENTO LEGAL}

Já com esta conceituação do juramento processual podemos nos perguntar, então, sobre a informação que as fontes judiciais já mencionadas nos mostram sobre a fórmula do juramento. Acerca do tema, a primeira coisa que deve ser dita é que em tais papéis encontramos uma variedade de fórmulas preconcebidas para tomar as informações das testemunhas, nas informações periciais, nas demandas e petições, nos registros oficiais, entre outros. Inclusive, dentro dos processos encontramos rastros do juramento promissório, não só quando uma testemunha promete dizer a verdade, mas, especialmente, quando se nomeia um perito ou auxiliar da justiça, que se compromete a desempenhar seus deveres com sujeição à norma ou à moral religiosa ${ }^{12}$, conforme o momento em que nos encontremos, ou o juramento constitucional que os funcionários (juízes e secretários) deviam fazer para tomar posse de seus cargos, sendo isto um bom exemplo de juramento político $^{13}$.

Enfim, dentro do processo, encontramos, pois, uma rede amplíssima de juramentos que impedem pensar em fronteiras claras entre juramento promissório e afirmativo, mas que também nos faz perceber o quão complexa pode ser esta instituição, complexidade que aumenta se vemos seu percurso em ondas de média e longa duração, como propusemos aqui.

\footnotetext{
12 Por exemplo: "En los mismos se presentaron los señores Indalecio Flores, Abelino Toro y Mariano Toro J. juramentados en debida forma, aceptaron el encargo y prometieron cumplir y desempeñar bien y fielmente el encargo, y firman...". (ARCHIVO HISTÓRICO JUDICIAL DE MEDELLÍN. Folio 7r, Documento 1720, 1858) ${ }^{13}$ No caso de: "En la ciudad de Sopetrán a 17 de enero de 1859 se presentó en el despacho de la prefectura el sr. José María Escovar a tomar posesión del destino de $3^{\circ}$ suplente del Juez del Circuito para que fue designado por la corporación municipal; y el prefecto por ante mí exigió al nombrado el juramento constitucional”. (ARCHIVO HISTÓRICO JUDICIAL DE MEDELLÍN. Folio 8v, Documento 1831, 1860)

Revista da Faculdade de Direito - UFPR, Curitiba, vol. 60, n. 1, jan./abr. 2015, p. 215-246.
} 
Um segundo assunto que não podemos perder de vista, uma vez fixado o significado do juramento processual no século XIX, relaciona-se ao fato de que os registros só nos apresentam as fórmulas usadas e refletidas no papel, mas o juramento, como veículo de constrangimento da consciência individual, vai além dessa mera fórmula usada. Porém, já é um bom avanço para os estudos de cultura jurídica registrar o percurso da fórmula em períodos de tempo mais longos.

E sobre esse percurso da fórmula encontramos três momentos relevantes nas fontes consultadas. Como primeiro momento denominaremos, convencionalmente, o juramento com forma religiosa correspondente às três primeiras décadas do século XIX. Ali encontramos, com maior claridade, formas muito mais religiosas nos juramentos processuais (pois abunda a referência à "religião do juramento" ou ao "juramento segundo o sinal da Santa Cruz", entre outros discursos ${ }^{14}$ ), assim como a constante do juramento em papéis que, posteriormente vão se perdendo. Por exemplo, as petições ao juiz são finalizadas, regra geral, com afirmações como "juro o necessário"15, algo que já não se observa nas alegações, demandas e demais documentos firmados pelas partes processuais no resto do século XIX. Aqui, claramente, a garantia da verdade do testemunho está baseada na autoridade da religião e no cumprimento de uma liturgia que alguns processos nos apresentam - por exemplo, jurar enquanto se persigna, enquanto faz um sinal da cruz com os dedos, enquanto toca um crucifixo, etc.

Ao segundo momento chamaremos o da transição, correspondente às décadas de 1840 e 1850, no qual encontramos discursos tanto em forma religiosa como em uma forma mais legal. Veem-se emergir, pouco a pouco, fórmulas com menos sacralidade, que dão conta de rituais com maiores intervenções do Estado e da Lei quando comparadas com as fórmulas usadas no início do século, o que se explica, em parte, pela maior consolidação do juiz letrado sobre o leigo ${ }^{16}$, bem como por uma paulatina estatização do direito, na qual desempenha um papel importante a Compilação Granadina (1845), que começa a rivalizar com normas jurídico-castelhanas e indianas nos fundamentos jurídicos citados pelos juízes. Aqui, o

\footnotetext{
${ }^{14}$ Recordemos, para dar um exemplo: "En consecuencia de lo mandado hizo su merced el señor juez comparecer ante mí a Don Francisco Rodríguez Zea que hace de Médico cirujano a efecto de que reconozca el cadáver de Don José María Acevedo y en su consecuencia el señor juez por ante mí le recibió juramento que hizo conforme a derecho por Dios Nuestro Señor y una señal de cruz por cuyo cargo ofreció decir verdad en lo que supiere y le fuere preguntado". (ARCHIVO HISTÓRICO JUDICIAL DE MEDELLÍN. Folio 2v, Documento 3467, 1809)

${ }^{15}$ Verbi gratia: "A vuestras señorías muy ilustres pido y suplico se sirva proveer como solicito por ser justicia que imploro y juro lo necesario, etc." (ARCHIVO HISTÓRICO JUDICIAL DE MEDELLín. Folio $1 r$ - $1 v$, Documento 3305, 1815)

${ }^{16}$ Referimo-nos à tensão existente entre a justiça leiga, fundamentalmente local ou concelhia, na qual predomina a aplicação de normas consuetudinárias, e a justiça letrada, fundamentalmente estatal, na qual predomina a aplicação de normas escritas castelhanas, indianas e, com maior força a partir da segunda metade do século XX, estatais. Sobre este assunto, cf. BOTERO (2010, p. 63-86).
}

Revista da Faculdade de Direito - UFPR, Curitiba, vol. 60, n. 1, jan./abr. 2015, p. 215-246. 
fundamento da verdade do relato é duplo, pois continuam usando fórmulas religiosas, porém já aparece, com força inusitada, uma remissão a ameaças estatais, terrenas, frente ao perjúrio. Não obstante, dada a complexa rede de processos citada no processo judicial do século XIX, não é possível estabelecer tal tipo de causalidade, de modo que se possa acreditar que a vacuidade do juramento foi a consequência da perda de confiança no testemunhado, apesar da dupla ameaça que se observava sobre quem jurasse em falso. Bem poderia se pensar que a vacuidade já estava presente - em constante crescimento, desde muito antes - se observarmos a história das ideias feita por Prodi (1992); ou, inclusive - e deixamos para outros estudos -, pensar que o reforço da ameaça estatal a quem jurasse em vão foi uma reação ante a vacuidade crescente, especialmente religiosa, do juramento.

Ao terceiro momento denominaremos "sob forma jurídica", na medida em que já quase desaparece de todo, no registro, qualquer remissão à ameaça e ao fundamento religioso do juramento, restando só a lei como o que dá forma ao juramento prestado. Esse momento resta patente com o uso de expressões como "juramentado legalmente"17, "juramentada em forma legal" 18 e "juramentada e legalmente examinada" corresponde, pois, a momentos de uma maior consolidação do Estado e da Lei, especialmente nos centros urbanos, assim como à redução sistemática feita aos juízes leigos e aos cabildos municipales (conselhos municipais). A centralização que se vê na força dos argumentos jurídicos fica patente com um juramento que se laiciza cada vez mais, passando, como nos dizem as fontes, de um assunto do juiz para ser uma competência secretarial ${ }^{20}$. Isso poderia nos levar a pensar, no momento, em uma perda crescente da eficácia simbólica, em sentido geral, do juramento como garantia da verdade frente ao juiz ${ }^{21}$, ainda em uso na prática. Evidente está que se poderia pensar que este momento de clara laicização das fórmulas processuais corresponde ao momento político neogranadino, isto é, ao predomínio do federalismo e dos movimentos liberais radicais, especialmente com a Constituição de Rionegro (1863), que dá lugar aos Estados Unidos da Colômbia. Não obstante, como diremos,

\footnotetext{
${ }^{17}$ Cf. ARCHIVO HISTÓRICO JUDICIAL DE MEDELLÍN. Folio 1r, Documento 2073, 1870.

${ }^{18}$ Cf. ARCHIVO HISTÓRICO JUDICIAL DE MEDELLÍ́N. Folio 3r, Documento 2073, 1870.

${ }^{19}$ Cf. ARCHIVO HISTÓRICO JUDICIAL DE MEDELLÍN. Folio 3v, Documento 2073, 1870.

${ }^{20}$ Recordemos a queixa de Muñoz (1874. Capítulo I, segunda parte, p. 58) ante a forma como se praticava o juramento, na década de 70 do século XIX: "Y después de rendida la exposición, recita el Secretario rápidamente $\mathrm{y}$ como sin conciencia de lo que dice, la disposición penal aplicable al falso juramento, y se concluye recibiendo éste. Nada más torpe, más ilegal, más absurdo y más perjudicial que este sistema y este desgreño, que pueden ser tan fatales para la inocencia como provechosos para el delito".

${ }^{21}$ Disse García Villegas (1993, p. 91) que a eficácia simbólica em sentido geral "es propia de toda norma jurídica en cuanto discurso institucional depositario del poder de nominación y de delimitación de lo legal y lo justo [...] Este sentido genérico de lo simbólico está vinculado de manera estrecha al concepto de 'aceptación del derecho desde el punto de vista interno' descrito por H. L. Hart [...] El derecho no puede existir sin la idea de aceptación, y esta idea se funda en una representación, en un símbolo".
} 
adiante, mais claramente, o processo de laicização não corresponde por inteiro com o aparato ideológico do partido político no poder, na medida em que o estatismo-legicentrismo obedece a forças de maior alcance, inicialmente retira qualquer outro poder dos elementos jurídicos e, posteriormente, abrange em sua órbita de ação terrenos que antes não lhe pertenciam, como o matrimônio e o direito de família (patrimônios do direito canônico), já em pleno século XX.

Pois bem, o fato de fazermos uso do termo "forma" não implica que estamos falando pejorativamente de um "formalismo" vão. A "forma" que rege o juramento não é um assunto estritamente "formal" 22 . Afirmamos, isso sim, que a religião e/ou a lei é o que "dá forma" ao juramento e constitui a ameaça que deveria (e muitas vezes o faz) constranger a consciência individual. Assim, o formalismo no ritual do juramento é um antídoto contra a malícia popular, ao mesmo tempo que mantém seu simbolismo, fonte de sua autoridade (LÉVY BRUHL, 1959, p. 388). Ademais, como já se disse, recorrendo a Lévy-Bruhl (1959) e a Prodi (1992, p. 22-3), o uso de fórmulas, na sua maioria pré-configuradas (o que explica sua constante repetição), não implica, per se, um desvalor do juramento. Ao contrário, só se sabe a fórmula rígida e se pronuncia efetivamente se podem comprometer a alma, o corpo e os bens. A importância da instituição explica a suposta rigidez na fórmula, ainda que, vale repetir, dita rigidez seja dinâmica. As fórmulas se repetem e são rígidas, em um mesmo espaço e tempo, em suas palavras e rituais, porém estes se transformam e mudam no espaço e no tempo na medida em que o juramento é, antes de tudo, dinâmico. Ademais, não podemos ignorar que, por economia processual na mão do escrivão, a fórmula termina repetindo-se no processo, tal como mostra sua própria experiência no ofício ou como seu sentido lhe diz que soa melhor. Pouco se poderia dizer a um escrivão por não ter a iniciativa no momento de relatar o que ocorre em um processo que é mais oral que escrito. E se a mesma mão que registra os fatos varia constantemente a fórmula usada para jurar, isso sim poderia ser um bom sinal de que o juramento já não tinha o rigor e a ameaça que o haviam caracterizado em momentos anteriores.

Igualmente, a "forma" que dá lugar ao juramento processual nos alude a uma múltipla rede de forças fundamentadoras do mesmo, rede que, não obstante, é dinâmica, transformando as forças e os pesos com o decorrer do tempo. Então, estamos ante um juramento que advém de normas jurídicas e de práticas morais e religiosas. Frente às normas jurídicas estamos, igualmente, ante um fundamento duplo, na medida em que o juramento, ao

\footnotetext{
${ }^{22}$ No processo judicial próprio do Antigo Regime, as formas, como o juramento, permitem assegurar a boa e reta conduta do juiz, assim como a verdade material, a qual se busca para poder restituir equilíbrios perdidos, tudo dentro do marco da equidade cristã. Cf. MARTÍNEZ, op. cit., p. 209-39.

Revista da Faculdade de Direito - UFPR, Curitiba, vol. 60, n. 1, jan./abr. 2015, p. 215-246.
} 
ser uma ponte, vincula (ainda que não necessariamente de forma pacífica) o poder civil e o religioso, está duplamente atado a uma normativa tanto civil como canônica (recordemos que no século XIX não se pode negar um caráter jurídico ao direito canônico, em virtude do patronato e, depois, da Concordata com a Santa Sé), que deu lugar, entre outras coisas, às fortes tensões entre Estado e Igreja, como bem nos narra Prodi (1992) em sua excelente história do instituto ${ }^{23}$. Ademais, o juramento se fundamenta nas práticas religiosas, tanto populares (que um homem "culto" não duvidaria em chamar "supersticiosas", "inferiores" ou "bobas" 24 ), como mais institucionais (como as que se desprendem dos catecismos tão populares em sua época), que dão conta de sanções tanto nesta vida (não só por parte do Estado, mas inclusive sanções derivadas de males, enfermidades, acontecimentos terríveis, etc., que aconteceriam a quem cometesse perjúrio), como na outra (especialmente, o compromisso da alma, que seria um dever sério a se enfrentar no juízo final).

Porém, além destas reflexões, o mais relevante - apesar dos desejos do pesquisador é reconhecer que essas fontes (as judiciais), embora importantes e devendo ser afrontadas, não permitem por si mesmas chegar a conclusões precisas e definitivas sobre o juramento na cultura; é dizer, do mero estudo dos registros judiciais só se poderia chegar a conclusões limitadas sobre o percurso das fórmulas usadas no juramento, mas não se poderia chegar com isso a demonstrar sem dúvida uma laicização do juramento na sociedade, nem, muito menos, considerar-se temas da religiosidade tal como era vivida no século liberal. São, pois, fontes valiosíssimas para dar conta das "formas" jurídicas e dos sistemas administradores de verdade nas culturas jurídicas, mas não vão mais além para um historiador do direito, nem seriam determinantes em estudos de culturas populares, ainda que forneçam indícios relevantes. Por outras palavras, dão boas pistas para decifrar uma cultura jurídica (isto é, para nossa pesquisa, a vivência do direito nos contextos mais próximos ao processo), inclusive dão muito mais

\footnotetext{
${ }^{23}$ Especialmente nos capítulos V e VI.

${ }^{24}$ Assim foi qualificado Evaristo Galiano, não só pelo jurista-periodista Muñoz (op. cit., especialmente capítulo XXIV, segunda parte, p. 174-7), mas por muitos outros homens cultos, médicos, advogados, juízes, no famoso processo do Aguacatal, entre outras razões, por suas crenças supersticiosas, que se refletiram, para dar um exemplo, em sua negativa em jurar em certo sentido que o livraria de toda suspeita por medo de ser picado por um animal. Resulta que Evaristo Galiano se negou a jurar em um sentido que poderia favorecê-lo porque poderia ser objeto de maldições (por exemplo, ser picado por um animal), porém terminou por jurar, depois, comprometendo a responsabilidade de outras pessoas nas quais recaíram as suspeitas do Fiscal do crime - é dizer, de Muñoz, o autor da causa célebre. Em certo momento do processo, suspeitou-se da veracidade do relatado por Evaristo sob juramento, por sua condição de "imbecil", mas ali Muñoz disse: "Este hombre que ha demostrado bastante conciencia o bastante miedo a la ley para denegarse a rendir un juramento en apoyo de una mentira, declara bajo la gravedad de las sanciones religiosa y legal, contra personas a las cuales no ha profesado nunca odio alguno, y como consecuencia forzosa, comprometiéndose a sí mismo". (Ibid., capítulo XXV, segunda parte, p. 178). Observe-se, pois, como, ante um juramento processual de forma legal, o sentimento religioso (supersticioso ou não) continua sendo um critério que, inclusive quem fora o Fiscal que ouviu o dito juramento, não o ignora no momento de defender este relato dentro do processo criminal.
}

Revista da Faculdade de Direito - UFPR, Curitiba, vol. 60, n. 1, jan./abr. 2015, p. 215-246. 
informação sobre a cultura jurídica que um estudo descritivo da normativa vigente, mas não são suficientes. Recorde-se que estamos ante uma pesquisa que pretende ir além, sem negar sua importância, de uma história do direito baseada no law in books - seguindo a exitosa metáfora de Pound (1910, p. 12-36) - para rastrear como se vivia, como se sentia nos contextos culturais próximos a esse direito vigente; isto é, um law in action.

É por isso que, para poder fazer marcos compreensivos do juramento processual, devemos partir das fontes judiciais, mas é preciso ir mais além. Efetivamente, fazemos uso, em nossa descrição de fontes, de uma variada informação de fontes primárias; é dizer, documentação da época e a normativa que deem uma estrutura à função judicial que revisamos. Porém, a norma só nos diz o que estava no papel como obrigatório, mas não como se vivia na cultura o obrigatório. Então, um bom marco normativo tampouco nos permite chegar a um porto seguro para nossas intenções, pelo que se tornou preciso buscar mais fontes.

Foi assim que recorremos às causas célebres, aquele gênero literário da belle epoque (MAZZACANE, 2011, p.9-40), especificamente a do "Crime de Aguacatal" (MUÑOZ, 1874), que muita informação nos deu sobre o juramento processual na década de 70 do século XIX, sobre a importância do juramento para a obtenção da verdade e as ameaças estatais e religiosas (incluindo aqui as supersticiosas) contra quem jurasse em falso. E é o que a causa célebre, que tanto consultamos para este trabalho, nos deixa evidente - que o juramento (sob forma jurídica, como se praticava nesse momento) estava já não só em um processo lento, mas seguro, de laicização, senão que, ademais, estava se tornando supérfluo dentro do processo, apesar das críticas que Muñoz (1874, p. 57-8) faz por tal assunto "secretarial” (pois também nos diz que, pouco a pouco, era mais um assunto de secretários que de juízes a tomada do juramento). Ademais, serve este caso para demonstrar a importância que pode ter a literatura como uma fonte a mais nos estudos de história do direito ${ }^{25}$.

Sem embargo, para lograr uma maior compreensão do fenômeno, era necessário ampliar as fontes, para incluir a literatura especializada.

\section{LITERATURA ESPECIALIZADA}

Analisadas as fontes primárias que apresentamos em nosso trabalho, passamos com maior confiança às fontes secundárias. Essa opção de usar as fontes secundárias só agora é

\footnotetext{
${ }^{25}$ Tanto pela forte vinculação entre o mundo jurídico e o literário no século liberal (PETIT, 2000), quanto como uma forma de renovação metodológica na história do direito, fazendo-se assim eco da linha traçada por diversos movimentos acadêmicos que podemos sintetizar como "Law \& Literature" (BOTERO, 2009, p. 37-65).

Revista da Faculdade de Direito - UFPR, Curitiba, vol. 60, n. 1, jan./abr. 2015, p. 215-246.
} 
feita, de certa maneira, para se evitar alguns perigos metodológicos de dar voz às fontes primárias depois de ler as interpretações feitas por outros. Aqui, nos debruçamos primeiro sobre as fontes primárias e, depois, sobre a literatura especializada. E foi esta que nos deu as bases que faltavam para poder oferecer, ainda que parcialmente (pois nunca será uma obra definitiva), um marco compreensivo da instituição vivente nos processos que agora investigamos. Devemos dizer que usamos vasta gama de fontes secundárias ou bibliografia especializada, mas nossa atenção se centrou especialmente em dois autores. O primeiro, a quem dedicamos mais tempo e espaço em nossa reflexões, foi Prodi, em sua obra prima $I l$ sacramento del potere: Il giuramento político nella storia costituzionale dell'Occidente, no qual relata o trâmite do juramento em geral, ainda que com grande ênfase no juramento político na história política e jurídica europeia. Prodi nos deu mais base em que nos sustentar, em especial sobre esse movimento de grande alcance que foi a laicização do juramento (de uma forma religiosa a uma forma legal), a sacralização da política e do Estado (do historicismo ao estatismo (FIORAVANTI, 1995, capítulo primeiro, especialmente p. 41-9) ou positivismo ideológico, diria Bobbio (1993, p. 139-241) - e a banalização do juramento, uma vez que perdeu sua capacidade de obrigar simbolicamente as almas (da força de uma sociedad jurada ${ }^{26}$ até a sociedade atual sem juramentos), entre outros aspectos. Enfim, como já dissemos, Prodi considera que o processo de laicização do juramento começou muito antes do século XIX, apresentando-o como uma linha que começa em Hobbes e continua com os autores mais memoráveis da modernidade, passando por Locke, Pufendorf, Kant e, especialmente, Rousseau (PRODI, capítulo nove, p. 441-87). Não obstante, esta fonte traz alguns riscos, que, se tivéssemos tomado-a como fonte única, facilmente nos conduziriam a algum erro: a) Ainda que faça reflexões gerais sobre o juramento, seu foco é o juramento político; b) Seu interesse especial se baseia em uma história institucional fundada nos grandes autores e nas grandes escolas do pensamento filosófico e político, estando com variados conteúdos probatórios pragmáticos, mas segue sendo, caso se deseje, uma história da evolução da instituição do juramento feita com base em uma história das ideias; c) Está centrada no campo europeu (ainda que esse último não seja uma crítica propriamente, visto que é inegável a forte comunicação atlântica entre a América e o Velho Mundo).

A outra fonte explorada, ainda que não tão amplamente como a anterior, são os vários trabalhos de Marta Lorente sobre o juramento constitucional, isto é, aquele juramento

\footnotetext{
${ }^{26}$ N. do T.: com este conceito se faz alusão a uma sociedade na qual as relações de poder e os tecidos sociais entre seus membros se constroem a partir de uma complexa rede de juramentos, fundamentalmente religiosos, dos estamentos entre si e dos membros para com o estamento. 
político - um juramento-voto, ao melhor estilo de Rousseau, diria Prodi (1992, p. 466-9) feito com elementos herdados do Antigo Regime que vinculou os deputados, os funcionários e a Nação espanhola com a normativa que se fazia nas Cortes, em especial com La Pepa (como é comum chamar a constituição gaditana de 1812). Este texto tem, entre outros méritos, o de fazer-nos compreender a importância do juramento do início do século XIX no mundo hispano-americano, como mecanismo de vinculação do indivíduo com a coletividade, e como o trânsito para uma modernidade jurídica passou por moldes herdados do Antigo Regime; isto é, o juramento continuou com seu papel fundamental próprio da sociedade jurada do passado para fundamentar novos elementos jurídicos mais ao tom do século liberal. Desta maneira, seria mais fácil falar de continuidade em vez de rupturas, caso se tenha em conta já não tanto o que diziam as próprias Cartas políticas expedidas à época, mas a forma com que elas foram tomadas, assumidas e concretizadas em culturas jurídicas específicas. Não obstante, essas fontes, como qualquer outra, devem ser postas em consideração com outras para se obter o melhor delas, visto que: a) Centram-se no juramento constitucional, isto é, no juramento político feito para obedecer às Cortes e à Constituição de Cádiz; e b) Referem-se a dois momentos muito concretos da história espanhola do início do século XIX (as Cortes durante a invasão napoleônica e o triênio liberal). Não obstante, é um trabalho muito mais concreto para o caso hispano-americano, caso se compare com o trabalho mais geral de Prodi, e, outra virtude, é que é mais pragmático, é dizer, já não indaga tanto o dito pelos autores mais relevantes na história das ideias políticas, senão quanto à forma em que foi jurada e à importância do juramento, mesmo na Nação espanhola, deixando evidente o componente da catolicidade, tão forte àquele momento, em todos os cenários da vida política e inclusive da cotidiana. Somemos que este texto nos convida a uma reflexão sobre se o juramento processual também serviu como forma de legitimação da normativa, a caminho da estatização, e do nascente Estado.

\section{LAICIZAÇÃO DO JURAMENTO PROCESSUAL}

Já podemos então contar com dois mapas que, ao sobreporem-se, apresentam-nos não só a extensão do terreno, mas o seu relevo. Assim, fontes primárias (registros judiciais, normas jurídicas da época e outra literatura feita por protagonistas), somadas às fontes secundárias, permitem-nos perceber, com maior segurança, a laicização do juramento processual ao longo do século XIX, além de um claro pragmatismo e empirismo que 
determinou a transformação, em ondas de longa duração, desta instituição ${ }^{27}$. Então, o transcorrer do juramento processual não foi tão claro como podia parecer na mente dos autores mais relevantes na época (o que explica a maior complexidade das instituições no law in action, caso se compare com a ideia de ditas instituições nas obras e nas normas: law in books) e se tratou de um desenvolvimento que não hesitou em utilizar materiais herdados baseados na força simbólica da "sagrada religião do juramento" e da religião popular, nem sempre autorizada pela Igreja, e da qual temos alguma notícia nessas fontes primárias consultadas.

Mas, voltando ao fenômeno da laicização do juramento, que é nossa principal conclusão, há muito que dizer. Recordemos que o juramento na sociedade jurada comunicava não só a religião com o jurídico-público, mas também determinava o rumo da dualidade Igreja-Estado (em um sentido amplo, claro está). Justamente por isso Prodi confia, e cremos que com razão, que a partir do juramento se pode fazer um rastro da história do pensamento político, do Estado e da Constituição no Ocidente. A laicização do juramento implicou, pois, a passagem, de uma dualidade interativa (com tensões e acordos ao longo da história) a uma progressiva debilitação da capacidade de diálogo e de exercício de limite que tinha a religião e a Igreja romana sobre o Estado, o que se pode rastrear, ademais, com o estudo da lide que gerou a continuidade ou não do patronato uma vez que ocorreu a Independência. Isto poderia ser chamado como um monismo, para opô-lo à dualidade de que já se falou, mas realmente a Igreja não foi absorvida pelo Estado, na medida em que esta não se nacionalizou, é dizer, não se estatizou, senão que foi reduzida em sua capacidade de controle e limite, para o bem ou para o mal, conforme a opinião, dos assuntos do governo e do Estado. Melhor denominá-lo estatismo (em seus efeitos políticos) e legicentrismo (em seus efeitos jurídicos). Inclusive, nos momentos de reivindicação da religião como motor de construção da Nação (referimo-nos ao movimento da Regeneração, que determinou os rumos da política colombiana a partir do último quarto do século XIX), a forte relação entre política e religião não implicou um desvanecimento da força que levava atrás de si o juramento sob forma jurídica, na medida em que o Estado já havia deposto progressivamente, do processo judicial, outros poderes moderadores, como a própria Igreja.

Outro componente importante da laicização do juramento processual relaciona-se com a progressiva perda do valor simbólico, como garantia de verdade, que o juramento

\footnotetext{
${ }^{27}$ Lorente (2007), por exemplo, esclarece-nos como o passo para a modernidade não se fez com os moldes puros dos teóricos, mas com estratégias mais pragmáticas, fazendo uso de materiais herdados, como, por exemplo, a tentativa de instrumentalizar a Igreja Católica para assegurar-se a lealdade da Nação espanhola, sujeito soberano segundo a própria constituição gaditana.
} 
gerava no juiz. Antes, não esqueçamos, não havia processo que prescindisse das testemunhas, principal mecanismo de prova, e não havia testemunha válida se não houvesse rigor no juramento, pelo que a perda da eficácia simbólica no sentido geral do juramento caminha ao lado de uma maior desconfiança do testemunho ${ }^{28}$. Inclusive, esta diminuição do valor do juramento já pode ser vista quando, em pleno século XIX, logra-se institucionalizar constitucionalmente a proibição de exigir o juramento ao acusado de algum delito, o que deixa claro uma redução progressiva de seus âmbitos. E essa perda do valor simbólico do juramento dentro do direito vem associada - sem poder falar, necessariamente, de uma causalidade - à sua progressiva vacuidade, é dizer, a constante perda do sentimento ou consciência que se sentiria vinculada à verdade de forma muito mais forte se houvesse o juramento. Então, um juramento sem valor simbólico e vazio quanto ao sentimento de submissão e ao medo ante as ameaças explica seu paulatino desaparecimento, por supérfluo. Mas, isso não se logrou dentro do processo da noite para o dia - é algo que só se pode rastrear, como aqui se fez, em estudos de longa duração. Mesmo um estudo de um século apenas permite ver que estes movimentos correspondem a ciclos mais longos, pois isto começa muito antes. Prodi (1992, p. 442-8), por exemplo, já situava seu início na mente de Hobbes, no século XVII, e se verifica muito depois, em pleno século XX.

Ademais, esta perda do valor simbólico do juramento como garantia de verdade abre luzes para uma história dos sistemas de administração de verdade dentro das formas jurídicas $^{29}$, em especial dentro do processo, na medida em que assistimos ao aumento do valor simbólico de outras provas, não tão recorrentes nos processos judiciais do Antigo Regime, como a documental e a pericial, esta última associada, com a força que isso implica, à ciência positiva (em especial a medicina forense $\mathrm{s}^{30}$ ), que, com a arrogância que a caracterizou no decorrer do longo século XIX, chegou a sustentar sua informação no processo já não com a coerção do juramento, mas com a "objetividade" do conhecimento científico. Afinal de contas, estamos em um processo no qual se pretende suplantar, segundo a mente do positivista, a "especulação", e a "superstição", pela ciência.

Então, a laicidade do juramento implicou, com o tempo, uma mudança na equação que lhe dava forma. No processo mais religioso, o juramento, tanto o político como o

\footnotetext{
${ }^{28}$ As testemunhas, no processo judicial do Antigo Regime, foram, no final das contas, "las pruebas concebidas como los mecanismos idóneos de los que dispone el juzgador para alcanzar esa verdad que debe guiar la acción de todas las partes implicadas. Porque será la declaración de los testigos el elemento más relevante de cara a la obtención de esa verdad, con arreglo a la cual deben actuar las partes implicadas y el juez, regido por la equidad en todas y cada una de sus conductas". Cf. MARTÍNEZ, op. cit., p. 225.

${ }^{29}$ Conceito que tomamos de Foucault (1996).

${ }^{30}$ Assunto já bem trabalhado, em relação ao século XIX, por Foucault (1990). Cf., ainda, FOUCAULT (2001). Revista da Faculdade de Direito - UFPR, Curitiba, vol. 60, n. 1, jan./abr. 2015, p. 215-246.
} 
processual, partia de uma tríade: o indivíduo que jura com uma forte carga simbólica sobre suas costas, a divindade que era testemunha da veracidade do relatado ou da promessa feitos sob juramento e o poder público (o Estado, por meio de um juiz, fiscal, escrivão, secretário, etc.), que recebia o informado confiando na sua veracidade pelo simbolismo do próprio ato e do particular sentimento que estava por trás. Já no juramento mais estatista possível, o Estado (e a lei) substitui à divindade ou, simplesmente, a exclui, enquanto "dá forma" ao ato. Jura-se pela lei, pelo Estado, pela pátria, pela sociedade. O Estado, ao mesmo tempo, recebe o juramento e é testemunha da veracidade e do compromisso de fidelidade de quem jura. Isto se associa, ademais, ao medo que constrangia o indivíduo no momento de jurar, na medida em que, no juramento religioso, as sanções a quem cometesse o perjúrio não só são terrenas, mas também, sendo isto o mais grave para sua consciência, são divinas: o pecado mortal. Já com a progressiva laicização do juramento, a coação à consciência passa, pouco a pouco, da ameaça com o pecado para a da pena corporal. O próprio Estado ameaça, com sua atuação, a quem jurar em falso, pelo que, pouco a pouco, deixa de fazer uso do discurso religioso. Este não desaparece da cultura popular, mas sim é minimizado em seus efeitos jurídicos na instituição que estudamos. Estamos, não nos esqueçamos, em épocas de crescente legicentrismo. E dali, do juramento laicizado, já estamos ad portas do seu caráter supérfluo. Recordando LévyBruhl (1959, p. 394. Tradução, pelo autor, do francês): "El prestigio del juramento está vinculado con el misterio que lo rodea. Si el misterio se aclara, toda la originalidad de la institución se encuentra aniquilada."

Sem embargo, o assunto não é tão claro como se poderia pensar nas poucas folhas que contêm este estudo. O juramento dentro das culturas jurídicas vai se laicizando, mas não se pode acreditar que as formas que dão lugar ao juramento processual estejam indefectivelmente conectadas com as formas em que se vive a religião católica na cultura mais ampla. Se fosse assim, quanto menos alusão ao religioso no processo, menos religiosidade haveria entre as gentes; e isto não ocorreu necessariamente. Os sentimentos religiosos vividos pela Igreja e pelas gentes não foram afetados com a mesma intensidade com que vemos a transformação do juramento no processo judicial. Um fervoroso cristão, por mais forma legal que tivesse o juramento, por mais ato secretarial que este tivesse, teria, por seu sentimento religioso, feito o juramento no processo judicial como um dever derivado do segundo mandamento da Lei de Deus, com o consequente medo das sanções divinas. Ademais, não nos esqueçamos que, no plano político, o sentimento religioso era compartilhado, em termos gerais, tanto por liberais como por conservadores, discutindo-se, isso sim, no que se refere à Igreja, sobre o tom das relações que deveriam existir entre esta e o 
Estado $^{31}$. Inclusive, recordando as fontes já assinaladas, várias pessoas, em momentos de juramento legal, negavam-se a jurar qualquer coisa por medo de sanções não estatais (isto é, maldições como a enfermidade, a mordida de animais, a ruína econômica, etc.). O que vemos, pois, é simplesmente uma deposição progressiva dos argumentos religiosos do ato processual de tomar o juramento a quem devia jurar, segundo a lei; até ali podemos chegar, no momento.

Claro está que o que poderia se dizer, deixando para melhores estudos seu desenvolvimento, é que o juramento religioso foi um meio importante na constituição do sujeito católico, primeiramente o vizinho católico e, depois, o cidadão católico (fruto dos primeiros anos de constitucionalismo); mas, conforme vamos passando ao juramento legal, evidencia-se uma cisão dentro do sujeito moderno, fruto do vazio religioso do conceito mesmo de cidadão, a partir da perspectiva jurídica, e de uma religiosidade sentida como fundamento moral, a partir da perspectiva sociocultural. Trata-se de ser cidadão (com seus conceitos de lei e Estado como suportes ideológicos) e cristão, mas em planos progressivamente diferentes.

Então, o que fazer se reconhecemos que a laicização do juramento processual não permite falar, per se, de uma laicização da sociedade em geral? O que vêm em nossa ajuda são os autolimites do historiador do direito (que deve reconhecer sua pouca capacidade para estes assuntos, deixando-os à mão, como se fosse uma corrida de revezamento, dos historiadores profissionais e antropólogos) e o uso de variadas fontes primárias e secundárias que corrigem as deficiências reducionistas dos registros, ainda que todos os estudos se voltem a algo em construção e suas conclusões sejam parciais, pois as fontes são infinitas. E o registro reflete partes de uma realidade, mas não é a realidade (nem sequer a do processo, com seu forte componente oral, que sempre escapa ao calígrafo, por mais esmerado que este seja). O que poderíamos dizer, com nossos conhecimentos sobre registros, é que, enquanto estes vão aumentando em folhas, a fórmula do juramento - as palavras próprias que o juiz ou secretário usam para narrar que se tomou o juramento, como ordena a lei - vai compactando-se. E isso

\footnotetext{
${ }^{31}$ Cf. TIRADO (2007, p. 46-62). Ainda: SÁNCHEZ (2003, p. 67-8). Inclusive, em não poucos casos pode "harmonizar-se" o forte sentimento religioso com o progressivo avanço do estatismo-legicentrismo, que, para o caso que agora citaremos, implica um deslocamento do direito canônico de suas órbitas típicas de regulação. Disse J. M. Samper (1951, p. 258-63), político muito importante do século XIX: "El Estado de Antioquia, conservador, y tachado de "retrogrado", estableció en su Código Civil estas sencillas reglas: Es reconocido por la ley y produce efectos civiles, todo matrimonio legítimamente celebrado ante cualquier ministro competente, con las formalidades y condiciones exigidas por la respectiva Iglesia, siempre que se haga constar debidamente, ante la autoridad pública, la celebración del acto. Cuando los contrayentes no pertenezcan a ninguna Iglesia, o no haya ministro de su culto que pueda autorizar el matrimonio, deberán celebrarlo conforme a las reglas que establece el Código Civil. Nada más justo, más sencillo, más verdaderamente liberal que este procedimiento, establecido por una Legislatura a quien sus adversarios calificaban de "retrógrada". Pues, a despecho de la justicia y la razón, la mayoría radical del Senado de 1876 anuló los artículos del Código Civil de Antioquia que tan noblemente organizaban el matrimonio".
}

Revista da Faculdade de Direito - UFPR, Curitiba, vol. 60, n. 1, jan./abr. 2015, p. 215-246. 
explica por que a confiança no informado se vai deslocando do juramento ao próprio relato e a outras provas. É a coerência - segundo o critério do juiz - do próprio relato da testemunha, do perito ou da parte, assim como outras provas respaldadas na "objetividade" da ciência, e não mais o juramento, que respalda o relatado, que termina por influenciar ou não a decisão judicial. Dito em outras palavras, as mudanças nos sistemas de prova e de sua correspondente valoração implicaram que, com o passar do tempo, o juramento deixasse de ser considerado um instrumento pleno de prova, e nem sequer uma garantia crível dentro do testemunho. Neste contexto, "o emprego do juramento na justiça cai, necessariamente, em decadência". (LÉVY-BRUHL, 1959, p. 393. Tradução, pelo autor, do francês para o espanhol. Tradução nossa, do espanhol para o português).

Assim, com os próprios registros, somados às outras fontes consultadas, mas com os limites já assinalados, podemos afirmar que a laicidade progressiva do juramento vai acompanhada de uma progressiva perda de seu valor simbólico como garantia de verdade dentro da cultura jurídica que permeia o processo. Passa a ser uma fórmula da qual se presume, pouco a pouco, seu vazio sentimental, e é tomada cada vez mais como uma formalidade processual não iludível, ainda que as culturas populares possam viver com uma força diferente. Estamos, pois, aproximando-nos de considerar o juramento como uma medida cada vez mais supérflua no ânimo de aproximar o juiz da verdade, ao mesmo tempo que, progressivamente, o juiz evolui para já se conceber não tanto como um rastreador da verdade, mas como um aplicador de normas estatais a partir de sistemas de imputação ${ }^{32}$. O juramento perde, paulatinamente e desde a perspectiva do juiz, solenidade e oportunidade, seguindo as palavras críticas de Muñoz ${ }^{33}$.

\section{TENSÕES, USOS E LINGUAGENS A PARTIR DO ESTUDO DO JURAMENTO}

Com nosso interesse em ir além das normas vigentes, sem abandonar a história do direito, podemos nos dar conta do uso (significado) do juramento em diversas linguagens que

\footnotetext{
${ }^{32}$ Como já dizia Kelsen (2005, p. 96, parágrafo 18, capítulo III): "En los enunciados jurídicos, con los que describe ese fenómeno, no se utiliza el principio de causalidad, sino un principio que, como demuestra este análisis, puede ser caracterizado como imputación". Queremos chamar a atenção para o fato de que nem sequer os conceitos de uma ciência pura do direito podem aplicar-se atemporalmente, sob pena de caírem no anacronismo mais cruel. A proposta de uma ciência jurídica neutra, pura, objetiva, baseada na imputação, é, ademais, tão determinada por espaços e tempos vitais concretos como pode ser a proposta de um direito atado à religião (do juramento), à moral, ao costume, à verdade, à causalidade, etc.

33 "Otros de los puntos sobre los cuales queríamos llamar la atención, eran la solemnidad y la oportunidad del juramento, lo mismo que la atención a las exposiciones de los testigos, en el momento en que las rinden [...] Hay enorme diferencia entre el testigo que declara bajo la impresión de un juramento solemne y de su correspondiente sanción penal y el que lo hace como quien habla naturalmente en una conversación ordinaria". Cf. MUÑOZ, op. cit., capítulo I, segunda parte, p. 57-8.
}

Revista da Faculdade de Direito - UFPR, Curitiba, vol. 60, n. 1, jan./abr. 2015, p. 215-246. 
confluem no processo judicial. Se estamos de acordo com Wittgenstein (1953, p. 20, parágrafo 43), para quem o significado de uma palavra está em seu "uso" na linguagem ${ }^{34}$, poderíamos afirmar que o juramento, ao ter diversos usos - como vimos até agora -, tem não só diversos significados, senão que, também, dá conta de várias linguagens. Ademais, se adicionamos, com Foucault $(1996)^{35}$, que as práticas e os usos geram sujeitos históricos e que as formas jurídicas refletem poderes, alguns ocultos em uma microfísica, que devem ser revelados pelo pesquisador, temos que assumir a pergunta sobre a forma na qual as linguagens se fazem a partir desta ritualidade processual, para definir tanto uma subjetividade moderna como uma relação do homem com a "verdade" histórica mediada pelo poder do direito. Assim, em primeiro lugar, falamos da linguagem estatista-legicentrista que, em seu constante crescimento e fortalecimento, especialmente nos núcleos urbanos, vai passando de um uso instrumental da religião (poderia se dizer, só para esta perspectiva) para assegurar a veracidade do dito da testemunha, do perito, das partes, dentro do processo, a um juramento na forma legal. Mas nessa linguagem estatista, em construção, só poderia caber como sujeito quem pudesse prestar juramento válido. Isto explica, pois, o rechaço a todo aquele que não pudesse prestar um juramento religioso, como o ateu, o não-católico, etc. Recordemos, ademais, que o rechaço ao ateu na história das ideias modernas (Moro, Hobbes e Locke, entre outros) se deveu ao fato de que não podia prestar juramento e, portanto, o Estado não podia confiar nem em seu relato nem em sua lealdade. Então, o rechaço social e político a quem não podia jurar, política ou processualmente, também se vivencia no progressivo processo de laicização que via no juramento um ato acessório, mas importante para o Estado, e só por isso poderia ter alguma utilidade. Isso também explica por que se aceitava sem problema o juramento em sede processual daqueles que não podiam fazer um juramento político individual, como a mulher, que possuía alma que poderia ser amedrontada pela religião e corpo que poderia ser amedrontado pelo Estado. Portanto, ela, na medida em que possuísse informação sobre uma verdade buscada pelo juiz, podia jurar processualmente.

Não obstante, nessa linguagem as coisas também não são claras, dado que em seu interior se evidenciam tensões que, pelo momento e por economia na exposição, não podemos desenvolvê-las, embora possamos mencioná-las neste texto. E também porque não há, em si, uma mesma justiça que sobreviva ao "longo século" para crer que, sem mudar o sujeito, mudam suas propriedades.

\footnotetext{
${ }^{34}$ No original em alemão: "Die Bedeutung eines Wortes ist sein Gebrauch in der Sprache".

${ }^{35}$ Ativemo-nos inicialmente à tradução para o espanhol das conferências que este autor ditou no Rio de Janeiro em 1973, editadas em português em 1978. 
Essas tensões podemos reduzir, com os perigos que implica querer abarcar a complexidade em poucas páginas, a três: A) Tensão entre as linguagens expressadas nas normatividades, na medida em que há tensão entre o sistema jurídico herdado (Partidas de Afonso X, Leis das Índias, etc.) e o novo sistema jurídico republicano que se constrói, paulatinamente, com ideais estatistas, e que vai se consolidando, inicialmente com compilações (como a Compilação Granadina de Lino de Pombo, 1845) e depois com códigos próprios ou importados (um estudo especial mereceria não só recepcionar o Código Civil de Bello mas também sua aplicação paulatina e a luta que foi travada para que isto fosse uma norma que superou as castelhanas no que se refere à sua aplicação judicial ${ }^{36}$ ). B) Tensão entre as linguagens dos juízes, pois fundamentalmente durante a primeira metade do século XIX se conviveu com uma justiça dupla; isto é, juízes leigos e juízes letrados, cada um com seus próprios usos e práticas (o que se evidencia, por exemplo, nas sanções e reclamações que os juízes letrados faziam dos deveres funcionais dos juízes leigos, quando estes últimos exigiam juramento no interrogatório ou confissão do réu de um delito ${ }^{37}$ ). C) Tensão entre formas religiosas (com seus anseios de aplicação de uma equidade emanada da justiça divina) e formas legais (com seus anseios de um Estado liberal de direito) que se vê, digamos, no decorrer do juramento.

Em segundo lugar, o uso do juramento na linguagem judicial nos dá pistas, mas não certezas absolutas, sobre o uso do juramento na linguagem popular dentro do século XIX. É que o juramento, com seus rituais, tem um valor no imaginário da sociedade que não se resume no processo, que se pode rastrear com outras fontes diferentes das jurídicas, para o qual estão muito mais preparados os historiadores profissionais e os antropólogos. Não obstante, os catecismos nos orientam, até onde nos interessa saber como fomentadores que somos de uma disciplina jurídica, sobre o valor que se dava ao juramento ${ }^{38}$. Ali se assinalava, com claridade, como o juramento era considerado louvável caso se fizesse para a honra de Deus, em virtude do segundo mandamento, pelo que nesses contextos o debate sobre se jurar

\footnotetext{
${ }^{36}$ Para isto é fundamental partir de GUZMÁN (1982, tomo I e II.). Igualmente, cf. LÓPEZ (2004. p. 129-233).

${ }^{37}$ São vários os casos que se poderiam expor acerca da mostra estudada, mas vale aqui recordar um. O juiz letrado Pantaleón Arango, atuando como advogado de pobres, alega, ante o juiz letrado das finanças, a inconstitucionalidade dos interrogatórios que um juiz paroquial, não letrado, adiantou com os defendidos por Arango, já que a justiça local lhes exigiu juramento no momento de tomar sua declaração, tal como consta no registro: "En el mismo día, mes y año en presencia de testigos le tome la confesión a Sebastián Triana reo de contrabando al que le recibí juramento que hizo por Dios Nuestro Señor y una señal de cruz en el que prometió decir verdad en todo lo que supiere y le fuere preguntado; y preguntado su estado y vecindad dijo que era casado, y que era vecino de esta parroquia hace dos años". (ARCHIVO HISTÓRICO JUDICIAL DE MEDELLÍN. Folios 1r-1v, Documento 2341, 1833)

${ }^{38}$ Sobre a importância dos catecismos para a história do direito, cf. DUVE (2010, p. 131-45). Revista da Faculdade de Direito - UFPR, Curitiba, vol. 60, n. 1, jan./abr. 2015, p. 215-246.
} 
violava ou não o direito natural se reduziu a que não devia fazer-se um uso em demasia do juramento, pois com ele sempre se colocava a alma em risco (RESINES, 2002, p. 272-3) ${ }^{39}$.

Isso sim, o juramento, em caso de ser falso, implicaria uma série de ameaças que eram o respaldo de sua garantia de verdade: de um lado, como já se mencionou, as ameaças religiosas (que implicavam desde o pecado mortal, até, nas versões mais populares, maldições com consequências nefastas que se cobrariam inclusive nesta vida), e não podiam faltar, na linguagem pública, as ameaças estatais derivadas de sanções fundamentalmente penais (POMBO, 1845, p. 199) ${ }^{40}$. E ambas os tipos de ameaça estão em tensão entre si em seu uso na linguagem judicial. Basta ver como, com o juramento legal, a ameaça de sanção estatal termina por deslocar, ao menos em suas formas processuais expressas, as ameaças religiosas. Sem embargo, as culturas populares não tinham como evoluir da mesma maneira como desejariam as mentes dos juristas. Evaristo Galiano, o "bobo", que desvendou o caso do crime de Aguacatal, é um bom exemplo de como o medo de maldições é muito mais forte do que o medo de uma sanção do Estado, nos momentos de juramento legal. Então a forte raiz religiosa, em sua dupla dimensão (teológica e popular) segue sendo um fundamento para não desapreciar o juramento, inclusive o processual, apesar de seu uso na linguagem jurídica já nos falar de outros estágios, de outros significados, de outras linguagens. São ritmos e usos diferentes de secularização e laicização.

\section{CONCLUSÕES}

Enfim, esperamos ter conseguido oferecer argumentos favoráveis às seguintes afirmações:

a) Que o juramento pode ser classificado em juramento político e processual.

b) Que o juramento esteve no crivo dos teóricos, teólogos e juristas, que, de um lado, avaliavam se fazê-lo implicava o dever de dizer a verdade ou o dever de comportar-se de

\footnotetext{
${ }^{39}$ Igualmente, cf. IGLÉSIA CATÓLICA, op. cit., p. 349-57 (em especial o parágrafo 7), assim como muitos outros catecismos consultados.

${ }^{40}$ Recordemo-nos, por exemplo, da Compilação Granadina, Código Penal, artigos 427 (los testigos y peritos que declaren bajo juramento algo falso en negocio civil serán declarados infames y condenados a presidio por tres a nueve años), 428 (tratándose de negocio criminal en delito con pena corporal serán declarados infames y condenados a trabajos forzados por cuatro a doce años, y si fuese en delito con pena no corporal serán declarados infames más dos a ocho años de presidio), 429 (si los falsos testigos hubieran dado sus declaraciones por soborno o cohecho, sufrirán el "máximo de las penas señaladas" y una multa "igual al duplo de lo que hubieren recibido o esperado recibir"), 430 (los que sobornaren para dar juramento falso serán castigados "con la mitad a las dos terceras partes de la pena prescrita contra el testigo sobornado"), 431 ("Los que en cualquier otro caso que se les exija juramento depongan falsamente, sufrirán la pena de uno a cuatro años de presidio") e 432 (los que fueren preguntados en un acto oficial, sin juramento, y faltaren a la verdad serán "apercibidos y arrestados por uno a dos meses").
}

Revista da Faculdade de Direito - UFPR, Curitiba, vol. 60, n. 1, jan./abr. 2015, p. 215-246. 
maneira leal, ou, de outro lado, se era simplesmente um meio, respaldado inicialmente pela religião e, com o tempo, pelo Estado, de reforço ou de garantia do dever de dizer a verdade e do dever de comportar-se de maneira leal, predominando, nas altas esferas, a segunda postura.

c) Que o juramento tinha um componente de medo ou pressão psicológica pelas ameaças, religiosas ou estatais, que recaiam sobre quem mentisse ou não cumprisse com o prometido.

d) Que o juramento religioso não só foi bem visto pela Igreja (ainda que se sugerisse seu uso com medida e recato), senão que inclusive se considerou que desta maneira se honrava a Deus e se distanciava do demônio e da tentação do pecado (entre eles o de mentir) $)^{41}$.

e) Que o juramento religioso político é crucial para compreender a forma de atar o indivíduo (primeiro o "vizinho" e depois o "cidadão") aos grupos coletivos e de obter legitimidade às constituições e aos Estados hispano-americanos (como relata Lorente) e inclusive no hemisfério ocidental (como indica Prodi).

f) Que o juramento processual, no decorrer do século liberal, passa, progressivamente, de uma liturgia do poder sentida pela consciência cristã para uma forma processual laicizada, mas da qual, apesar da perda de seu valor simbólico, nunca deixou de estar presente nos registros, pelos possíveis efeitos jurídicos derivados de sua inobservância (como a ameaça de sanções penais ou a nulidade da atuação processual).

g) Que o juramento processual foi a forma de se assegurar a verdade do relato, sendo fundamental especialmente em momentos em que as principais provas nos processos analisados são apenas os relatos de uma parte, de uma testemunha, de um perito, etc.

h) Que o juramento foi proibido para a confissão (interrogatório do acusado) em matéria criminal pelas constituições republicanas, assunto que muitos juízes locais leigos, que aplicavam os costumes judiciais herdados, ignoravam, o que gerou várias queixas e processos ante a justiça letrada. Ademais, isso significou que o juramento, com sua grande carga simbólica, começou a retroceder ante a defesa judicial dos direitos de quem é julgado.

i) Que o juramento, por sua importância, era inicialmente, e como era de se esperar, religioso, o que levava a compromissos com a verdade sob pena de pecado e de perjúrio, mas que, com o tempo, é-lhe dada "forma" legal, retirando do papel do processo as alusões religiosas.

\footnotetext{
${ }^{41}$ É Decugis (1942, p. 131) quem nos recorda como o juramento, em seus inícios místicos mais antigos, estava associado a ritos para distanciar o demônio, seja como rechaço à futura heresia (que seria uma forma de juramento-promessa), seja como rechaço à tentação (em um juramento sobre a veracidade de um relato). 
j) Que o juramento é o reflexo, no micro, de assuntos que no macro se desenham nas tensas relações Estado-Igreja, como ocorria em relação ao patronato, tanto que o nascente Estado requeria a legitimação religiosa. Isso se relaciona com o rol do juramento em uma transição gradual de longo alento, de um dualismo Igreja-Estado (um dualismo em diálogo e em tensão permanente, porque, ainda que tenham sido duas entidades diferenciadas e limitadoras uma da outra, sempre buscaram o apoio mútuo para a satisfação de seus fins institucionais, em especial o relativo aos fins missionários - expansão da fé) a um dualismo excludente (que pode ser visto inclusive como um monismo: o estatismo-legicentrismo como o proprietário do público subordinando ou debilitando a Igreja e seu poder simbólico). Assim, o juramento processual passa de uma forma religiosa a um instrumento secularizado a serviço do Estado.

k) Que o juramento processual explica, em parte, uma transformação na atitude do jurista, em geral, e do juiz em particular, sobre a própria finalidade do processo. Com o juramento religioso o processo tinha como objetivo a restituição de equilíbrios perdidos (não só individuais mas também sociais), que se fazia obrigatório para o juiz chegar a verdade ${ }^{42}$. Mas, já em épocas de juramento sob forma jurídica, o estatismo-legicentrismo abre as portas para considerar, já em pleno século XX, que o fim do processo não é a verdade, mas a aplicação de normas sob relações de imputação e não de causalidade.

1) Que o caminho percorrido pelo juramento processual deixa em evidência a maior presença do pragmatismo e não tanto de uma pureza doutrinária, tudo em sintonia com a mentalidade coletiva atravessada por imaginários religiosos e deveres íntimos que, talvez hoje, já nos parecem desconhecidos.

m) Que o juramento processual dá pistas de uma vivência, de uns usos populares e imaginários coletivos do juramento, mas que não se pode acreditar que a laicização do juramento processual foi proporcional em sua força e impulso a uma dessacralização e desencanto das relações simbólicas nas culturas populares.

Porém, ademais, este trabalho também demonstra alguns ensinamentos metodológicos, não só no que se refere ao manejo das fontes, mas também em suas pretensões totalmente dogmáticas. Devemos dizer, uma vez mais, que estamos ante um trabalho que não pode se dar ao luxo dos grandes clássicos que (acreditam que) fecham, com a última página,

\footnotetext{
${ }^{42}$ Martínez (op. cit., p. 230-1) nos diz, sobre o processo no Antigo Regime, que: "La idea de un interés público, entendido como algo superior a los intereses de cada una de las partes que afecta a la vida social y al aspecto religioso de esa vida social, se coloca en un primer plano y condiciona las actuaciones todas. La verdad es el elemento a perseguir, pase lo que pase, caiga quien caiga y se invierta el tiempo que se invierta. Se comienza a hablar en esos tiempos de veredicto, como sinónimo de sentencia, para significar esa dicción de la verdad que debe culminar todo proceso".
} 
um tema. Já o dizia nosso Prodi (1992, p. 19. Tradução, pelo autor, do italiano para o espanhol. Tradução nossa, do espanhol para o português): "Talvez a era do livro concebido como produto finito e concluído ao qual a encadernação imprime o selo definitivo de completo e perpétuo, que as resenhas podem só elogiar ou maltratar, esteja por terminar”. E não podia ser para menos, se levarmos em conta que: a) Escolhemos, conscientes dos riscos, fazer uma história de uma instituição complexa em um longo decorrer do tempo - bom, um século é longo para muitos e curto para outros - para poder dar conta de ondas de longa duração. b) Não poderia ser definitiva uma obra que parte de fontes judiciais que, para serem compreendidas em um sentido mais além do estritamente normativo, impõem-nos recorrer a muitas outras fontes e, por tal remissão, sempre haverá algo novo a se dizer na medida em que crescem as fontes, primárias e secundárias. c) Nossa pretensão de uma história do direito mais além da estritamente normativa, mas sem chegar a ser uma história geral, implica estar em pontos cinzentos, rastreando uma cultura jurídica dentro de uma cultura maior, pelo que, desde os dois extremos, tanto para o historiador do direito normativista como para o historiador profissional, sempre será preciso algo mais. Esta é a tragédia e a solidão, parafraseando Caroni (2010), do historiador do direito que indaga por matizes e culturas: somos muito historiadores para os juristas (inclusive para os historiadores do direito normativistas) e muito juristas para os historiadores profissionais ${ }^{43}$.

Quisemos, pois, partindo dos registros judiciais, entender as conexões existentes entre o direito (caso se queira, a partir do law in books) e a cultura que lhe rodeia, é dizer, uma investigação sobre o law in action. Se pudemos esclarecer o leitor, por qualquer fonte - algo que sabíamos, desde o início, que era complexo e difícil - cumpriu-se a tarefa. E corresponderá a ele continuar estas indagações, aprofundando e ampliando os marcos de referência. Nós, de nossa parte, "juramos” descansar para tomar alento com o fim de seguir nossas indagações sobre a justiça do século XIX na Colômbia.

\section{FONTES E REFERÊNCIAS}

ARCHIVO HISTÓRICO JUDICIAL DE MEDELLÍN. Folio 1r-1v, Documento 3305, 1815. Folio $1 r$, Documento 2073, 1870.

\footnotetext{
${ }^{43}$ Parafraseando aqui a já famosa e contundente afirmação de Hans Thieme (1986, p. 25): “El historiador del derecho es, por lo general, entre los juristas un buen historiador, y entre los historiadores un buen abogado. No le es fácil satisfacer a ambos. Él es un ciudadano con doble nacionalidad, un sujeto mixto, en dos Facultades en las que se siente como fuera de casa, por así decirlo en dos zonas, y la carga que implica ser una frontera la sabemos nosotros hoy mejor que nunca". (Tradução, pelo autor, do alemão)

Revista da Faculdade de Direito - UFPR, Curitiba, vol. 60, n. 1, jan./abr. 2015, p. 215-246.
} 
. Folio $1 v$ y $2 r$, Documento 1419, 1833.

. Folio 2r, Documento 2839, 1845.

. Folio 2v, Documento 3467, 1809.

. Folio 3r, Documento 2073, 1870.

. Folio 3v, Documento 2073, 1870.

Folio $7 r$, Documento 1720, 1858.

. Folios 1r-1v, Documento 2341, 1833.

BOBBIO, Norberto. El positivismo jurídico. Madrid: Debate, 1993.

BOTERO, Andrés. El Quijote y el Derecho: Las relaciones entre la disciplina jurídica y la obra literaria. En: Revista Jurídica: Universidad Autónoma de Madrid (RJUAM), No. 20, 2009; p. 37-65.

La tensión entre la justicia lega y la justicia letrada durante la primera mitad del siglo XIX: el caso de Antioquia (Nueva Granada). En: Iushistoria - Investigaciones, Universidad del Salvador, Buenos Aires - Argentina, No. 3, 2010. p. 63-86.

BRADUEL, F. La historia y las ciencias sociales. Madrid: Alianza, 1980.

CARONI, Pío. La soledad del historiador del derecho: apuntes sobre la conveniencia de una disciplina diferente. Presentación de Italo Birocchi. Trad. Adela Mora y Manuel Martínez. Madrid: Universidad Carlos III, 2010.

COSTA, Pietro. Soberania, representação, democracia: Ensaios de história do pensamento jurídico. Curitiba: Juruá Editora, 2010.

DECUGIS, Henri. Les étapes du droit. Des origines a nos jours. Paris: Librairie du Recueil Sirey, 1942.

DUVE, Thomas. Catequesis y derecho canónico. Entre el Viejo y el Nuevo Mundo. En: SCHMIDT-RIESE, Roland (Ed.). Catequesis y derecho en la América colonial: fronteras borrosas. Madrid-Franfkfurt am Main: Iberoamericana y Vervuert, 2010. p. 131-45.

EHRLICH, Eugen. The Sociology of Law. In: Harvard Law Review, Vol. XXXVI, No. 2, December, 1922. p. 130-45.

FIORAVANTI, Maurizio. Appunti di storia delle costituzioni moderne. $2^{\mathrm{a}}$ ed. Torino: G. Giappichelli Editore, 1995.

FOUCAULT, Michel. La verdad y las formas jurídicas. Trad. Enrique Lynch. Barcelona: Gedisa, 1996. 
. Vigilar y castigar: nacimiento de la prisión. Trad. Aurelio Garzón del Camino. $18^{\mathrm{a}}$ ed. México: Siglo XXI, 1990.

Yo, Pierre Rivière, habiendo degollado a mi madre, a mi hermana y a mi hermano. (J. Vinyoli, Trad.) Barcelona: Tusquets, 2001.

GARCÍA VILLEGAS, Mauricio. La eficacia simbólica del derecho: examen de situaciones colombianas. Bogotá: Uniandes, 1993.

GUZMÁN, Alejandro. Andrés Bello codificador: Historia de la fijación y codificación del derecho civil en Chile. Santiago de Chile: Universidad de Chile, 1982. Tomo I y II.

IGLÉSIA CATÓLICA. Catecismo del Santo Concilio de Trento para los párrocos, ordenado por disposición de San Pio V, traducida en lengua castellana por el P. Fr. Agustín Zorita, según la impresión que de orden del Papa Clemente XIII se hizo en Roma en el año de 1761. (P. F. Zorita, Trad.) Cuenca: Imprenta de Don Fernando de la Madrid, 1803.

KELSEN, Hans. La teoría pura del derecho. Trad. Roberto Vernengo. México: Porrúa, 2005.

LÉVY-BRUHL, Henri. Réflexions sur le Serment. En: Études d'histoire du droit privé offertes à Pierre Petot. Paris: Librairie générale de droit et de jurisprudence, éditions Montchrestien, Jurisprudence Dalloz - Libraire du Recueil Sirey, 1959.

LÓPEZ, Diego. Teoría impura del derecho: la transformación de la cultura jurídica latinoamericana. Bogotá: Universidad de los Andes, Legis y Universidad Nacional de Colombia, 2004.

LORENTE, Marta. El juramento constitucional. En: GARRIGA, Carlos y LORENTE, Marta. Cádiz, 1812. La constitución jurisdiccional. Epílogo de Bartolomé Clavero. Madrid: Centro de Estudios Políticos y Constitucionales, 2007. p. 73-118.

. La Nación y las Españas. En: CLAVERO, Bartolomé; PORTILLO, José María y LORENTE, Marta. Pueblos, Nación, Constitución (en torno a 1812). España: Ikusager y Fundación para la libertad, 2004. p. 101-42.

. Las infracciones a la constitución de 1812: Un mecanismo de defensa de la constitución. Madrid: Centro de Estudios Constitucionales, 1988.

MARTÍNEZ, Faustino. El proceso canónico y la verdad. En: GONZÁLEZ-VARAS IBÁÑEZ, A. (Coord.). El Ius Commune y la formación de las instituciones de Derecho Público. Valencia: Tirant Lo Blanch, 2011 (en prensa). Capítulo VII.

MAZZACANE, Aldo. Literatura, proceso y opinión pública: Recuento de causas célebres entre el bello mundo, abogados y revolución. Trad. Andrés Botero. En: MAZZACANE, Aldo et al. Causas célebres y derecho: estudios sobre literatura, prensa, opinión pública y proceso judicial. Medellín: Universidad de Medellín, 2011. p. 9-40.

MUÑOZ, Francisco de Paula, El Crimen de Aguacatal. Medellín: Imprenta del Estado por León F. Villaveces, 1874. 
PETIT, Carlos. De la historia a la memoria. A propósito de una reciente obra de historia universitaria. En: Cuadernos del Instituto Antonio de Nebrija de Estudios sobre la Universidad, No. 8, 2005. p. 237-79.

PETIT, Carlos. Discurso sobre el discurso. Oralidad y escritura en la cultura jurídica de la España liberal. Lección inaugural curso académicos 2000-2001. Huelva: Universidad de Huelva, 2000.

POMBO, L. de. Recopilación de leyes de la Nueva Granada. Formada i publicada en cumplimiento de la lei de 4 de mayo de 1843 i por comisión del poder ejecutivo por Lino de Pombo. Bogotá: Imprenta de Zoilo Salazar, por Valentín Martínez, 1845.

POUND, Roscoe. Law in books and Law in Action. In: American Law Review, No. 44, 1910. p. 12-36.

PRODI, Paolo. Il sacramento del potere. Il giuramento politico nella storia costituzionale dell'Occidente. Bologna: Il Mulino, 1992.

RESINES, Luis. Catecismo del Sacromonte y Doctrina Christiana de Fr. Pedro de Feria. Conversión y evangelización de moriscos e indios. Madrid: Consejo Superior de Investigaciones Científicas, 2002.

SAMPER, José María. Samper, José María. Derecho Público Interno en Colombia: Del Derecho Constitucional Colombiano desde 1810 hasta 1886. Tomo 1. Bogotá: Biblioteca Popular de Cultura Colombiana y Prensa del Ministerio de Educación Nacional, 1951.

SÁNCHEZ, Gonzalo. Guerras, memoria e historia. Bogotá: ICANH, 2003.

THIEME, Hans. Ideengeschichte und Rechtsgeschichte. Gesammelte Schriften. I Band. KölnWien: Böhlau Verlag, 1986.

TIRADO, Álvaro. El estado y la política en el siglo XIX. Bogotá: El Áncora, 2007.

WITTGENSTEIN, Ludwig. Philosophische untersuchungen. Oxford: Basil Blackwell, 1953.

\title{
FROM THE RELIGION OF OATH TO THE SECULAR OATH: CONCLUSIONS OF A STUDY ABOUT THE EVOLUTION OF PROCESSUAL OATH IN COLOMBIA THROUGH THE NINETEENTH CENTURY
}

\begin{abstract}
This paper presents the conclusions of a large research that brings new lights into the process of laicization of the judicial oath through the nineteenth century in Colombia. Based on primary (trials, rules and literature - causas célebres) and secondary sources, it's analyzed the value of the oath as a guarantor of truth within the framework of the cultural purpose of the judicial procedure, the evolution of the oath (politically and judicially) in the modernity and the gradual passage of the religious oath to one of legal form into the Colombian judicial process. It also discusses the strong relationship between religion (both, educated and popular) and the procedural oath, all with the goal to contribute to the identification of the most important characteristics of the nineteenth-century legal culture.
\end{abstract}


KEYWORDS: Judicial oath. Judicial process. Laicization. Religion. Truth.

Recebido: 5 de fevereiro de 2015

Aprovado: 10 de março de 2015 